\title{
Efficacy of Polylactic-Co-Glycolic Acid Plate as a Graft Material in Septorhinoplasty
}

\author{
Jae-Yoon Kang ${ }^{1}$ D , Min-Su Kim ${ }^{1}$, Se Yeon $\mathrm{Im}^{1}$, Soo Kyoung Park ${ }^{1} \mathbb{D}$, \\ Ki-Sang Rha ${ }^{1}$ (i), and Yong Min $\mathrm{Kim}^{1,2}$ (D) \\ ${ }^{I}$ Department of Otorhinolaryngology-Head and Neck Surgery, Research Institute for Medical Science, \\ Chungnam National University College of Medicine, Daejeon; and \\ ${ }^{2}$ Department of Medical Science, Chungnam National University College of Medicine, Daejeon, Korea
}

\section{비중격 외비성형술에서 이식 재료로써 Polylactic-Co-Glycolic Acid Plate의 유용성}

강재윤 ${ }^{1} \cdot$ 김민수 $^{1} \cdot$ 임세연 ${ }^{1} \cdot$ 박수경 $^{1} \cdot$ 나기상 $^{1} \cdot$ 김용민 $^{1,2}$

${ }^{1}$ 충남대학교 의과대학 의학연구소 이비인후-두경부외과학교실, ${ }^{2}$ 충남대학교 의과대학 의과학과

Received January 28,2021

Revised March 11, 2021

Accepted April 19, 2021

Address for correspondence

Yong Min Kim, MD, PhD

Department of Otorhinolaryngology-

Head and Neck Surgery,

Research Institute for

Medical Science,

Chungnam National University

College of Medicine,

282 Munhwa-ro, Jung-gu,

Daejeon 35015, Korea

Tel $+82-42-280-7696$

Fax $+82-42-253-4059$

E-mail entkym@cnu.ac.kr
Background and Objectives Polylactic-co-glycolic acid (PLGA) plate has been recognized for its biocompatibility and biomechanical properties and used widely in various clinical fields. The aim of this study was to evaluate the usefulness and reliability of PLGA plate as a graft material in septorhinoplasty.

Subjects and Method Medical records were retrospectively analyzed for patients who underwent septorhinoplasty including extracorporeal septoplasty from January 2017 to June 2020. We evaluated demographics, diagnosis, operation techniques, and complications of PLGA plate as a graft material used in these patients.

Results A total of 33 patients were enrolled in this study. Twenty-eight were male and 5 were female. The median age was 32 years old. The follow-up period after surgery was 6-32 months, and the mean follow-up period was 18.03 months. The PLGA plate was used in unilateral spreader graft $(n=17)$, bilateral spreader graft $(n=10)$, batten graft $(n=3)$, strengthening of septal extension graft $(n=2)$ and columellar strut graft $(n=3)$, and fixing L-strut during extracorporeal septoplasty $(n=12)$. During the follow-up period, no patient experienced extrusion or exposure of the grafts. Mild complications, such as redness of the columella skin, granulation in the marginal incision site, and pain on the nasal dorsum were observed in three patients; these complications were temporary and patients improved with conservative treatments.

Conclusion The PLGA plate may be a useful graft material in correcting deviated nose especially when the harvested septal cartilage is insufficient and if used carefully in limited locations such as L-strut and columella.

Korean J Otorhinolaryngol-Head Neck Surg 2021;64(9):635-40

Keywords Allografts; Nasal septum; Polylactic acid-polyglycolic acid copolymer; Postoperative complications; Rhinoplasty.

\begin{abstract}
서 론
사비에 동반된 비중격 만곡증을 교정하기 위한 비중격 교 배부와 비중격에 대한 넓은 시야를 제공하여 동반된 변형을 교정하는 데 장점이 있다. ${ }^{1)}$ 개방비성형접근법을 통한 비중격 외비성형술 및 비중격 체외교정술(extracorporeal septoplas-
\end{abstract}

ty) 시 비배부의 변형된 비중격 교정은 필수이며, 이때 주로 This is an Open Access article distributed under the terms of the Creative Commons Attribution Non-Commercial License (https://cre
permits unrestricted non-commercial use, distribution, and reproduction in any medium, provided the original work is properly cited. 
비중격에서 채취한 연골은 가장 이상적인 이식 재료로써 펼 침이식(spreader graft), 버팀목이식(batten graft), 비중격 연 장이식(septal extension graft) 등의 술기에 이용된다. ${ }^{2-5)}$ 하 지만 사비환자의 경우 비골 및 비중격 골절 등의 외상 과거력 이 있는 경우가 대부분이고, 비중격 연골의 골화 및 심각한 변형이 동반된 경우가 흔해서 이식 재료로써 사용하기에 양 이 충분하지 않은 경우가 있다. 이 경우 비배부 비중격 변형을 교정하기 위해 이개연골이나 늑연골을 이용한 자가이식( $\mathrm{au}^{-}$ tologous graft) 혹은 이물이식(allograft)을 고려해야 한다. ${ }^{6-8)}$ 하지만 자가 늑연골이나 귀연골을 이용하는 경우는 침습적 이고, 수술 이후 공여부에 흥터, 혈종, 기흥 등의 부작용이 발 생할 수 있으며, 골화가 진행된 경우 충분한 양의 연골을 얻 을 수 없다는 단점이 있다. ${ }^{9)}$ 따라서, 이를 대체하기 위하여 polydioxanone (PDS), porous high-density polyethylene (pHDPE; Medpor ${ }^{\circledR}$; Stryker, Kalamazoo, MI, US), polylactic acid (PLA), polylactic-co-glycolic acid (PLGA) 등의 이물이식 재료들이 소개되어 왔다. ${ }^{9-12)}$

이들 재료 중 PLGA는 PLA와 poly-glycolic acid(PGA)로 이루어진 고분자로써 생체적 합성과 생체 역학적 특성을 인 정받아 임상적으로 다양한 분야에서 활용되고 있다. ${ }^{13)} \mathrm{PLGA}$ plate는 단단한 재질이지만 두께가 비교적 얇아서 돌출의 염 려가 없고, 가공하기가 쉬우며, 채 모양의 구멍들이 있어서 연 골에 봉합하기 쉽기 때문에 비성형술 시 다방면에서 활용도 가 높다. 본 연구에서는 외비성형술에서 PLGA plate를 이식 재료로 사용하였을 때 이물이식 재료로써 유용성과 안전성 에 대하여 알아보고, 다른 이물이식물과 비교하였을 경우의 장단점을 문헌 고찰을 통해 살펴보고자 한다.

\section{대상 및 방법}

2017년 1월-2020년 6월까지 충남대학교병원 이비인후과 에 입원하여 비중격 외비성형술 및 비중격 체외교정술을 받 은 환자들 중 PLGA plate를 수술 중 사용하였던 환자들을 대상으로 의무기록을 후향적으로 분석하였다. 총 112 명의 환 자 중 33명의 환자에서 PLGA plate를 사용하였고, 이 환자 들의 의무기록을 분석하여 성별, 나이, 진단명, 수술기록지의 수술 방법, 추적 관찰 기간, 합병증 등을 조사하였다. 본 연 구는 해당 기관 임상연구심의위원회의 승인(IRB FILE No. 2020-12-087)하에 진행되었다.

\section{수술 방법}

모든 수술은 숙련된 1 인의 술자가 전신마취하에 개방접근 법으로 진행하였다. 비중격 외비성형술은 비중격연골의 L형
지주를 보존하면서 비중격연골을 채취하고 만곡된 비중격골 부를 제거하여 비중격 교정술을 시행하였다. 비중격 체외교 정술인 경우 비중격의 재건을 위해 L형 지주 중 두부의 일부 분을 남겨둔 채 나머지 연골부와 골부를 모두 제거하였다. 비 중격의 교정을 위해 버팀목이식, 펼침이식, 비중격 연장이식, swing door technique, figure of 8 suture 등의 술기를 적용 하였는데, 채취한 비중격연골이 골화 또는 비틀림으로 인해 양이 충분하지 않을 경우 PLGA plate (Biobsorb $\alpha^{\circledR}, 29 \times$ $25.2 \times 0.3$ mm; OSTEONIC Co., Ltd., Seoul, South Korea) (Fig. 1A)를 이용하여 서로 다른 이식술을 시행하였다. 필요 에 따라 비골절골술, 비첨이식, 비배부융비술 등을 추가적으 로 시행하였다.

\section{$\mathrm{L}$ 형 지주 강화}

비중격 체외교정술 시 채취한 비중격연골이 부족한 경우, 새로 재단하여 만든 비중격연골(L형 지주의 미부)과 남겨진 비중격연골 두부(L형 지주의 상단부)를 결합할 때 PLGA plate를 이용하였다(Fig. 1). 채취한 비중격연골의 양에 따라 PLGA plate를 일측 또는 양측에 사용하여 5-0 PDS ${ }^{\circledR} \mathrm{II}$ (ETHICON, Cornelia, GA, US)로 여러 차례 봉합하여 비중 격연골을 안정화시켰다. 비중격미부는 전비극 부위의 골막에 3-0 coated VICRYL ${ }^{\circledR}$ (ETHICON, Cornelia, GA, US)로 봉 합하였다.

\section{펼침이식, 버팀목이식}

비중격연골 비배부의 만곡이나 변형이 관찰된 경우 채취 한 비중격연골의 양에 따라 일측 또는 양측에 PLGA plate를 이용하여 펼침이식을 시행하였다(Fig. 2). 비중격연골을 채취 하고 남은 L형 지주 부위의 만곡이 심한 경우 펼침이식과 별 도로 PLGA plate를 이용하여 버팀목이식을 일측 또는 양측 에 시행하였다(Fig. 3A).

\section{비주지주이식, 비중격 연장이식}

비주지주이식(columella strut graft)의 경우 하외측비연골 의 내측각이 변형되었거나 연골 자체의 강도가 약하여 비첨 의 지지가 약할 것으로 예상되는 경우, 혹은 추가적인 비첨 이식을 위한 비첨 지지가 필요한 경우에 시행하였다. 비주지 주이식을 위한 충분한 양의 비중격연골이 없는 경우에만 PLGA plate를 제한적으로 사용하였는데, 이개연골을 이용한 비주지주이식을 할 경우와 채취한 비중격연골 중 곧은 부분 이 없는 경우 PLGA plate를 두 개의 연골 사이에 끼워 넣고 봉합하여 노출이 안 되도록 주의하면서 비주지주이식을 강 화하였다(Fig. 3B). 
비중격 연장이식에 쓰인 비중격연골이 약하여 충분히 비첨 을 지지하지 못할 것으로 생각되는 경우 PLGA plate를 비중 격연장이식 연골에 덧대어 이식을 강화하였다. 이 때 PLGA plate는 비중격 연장이식보다 크기가 작게 디자인하여 돌출 되지 않게 하였다.
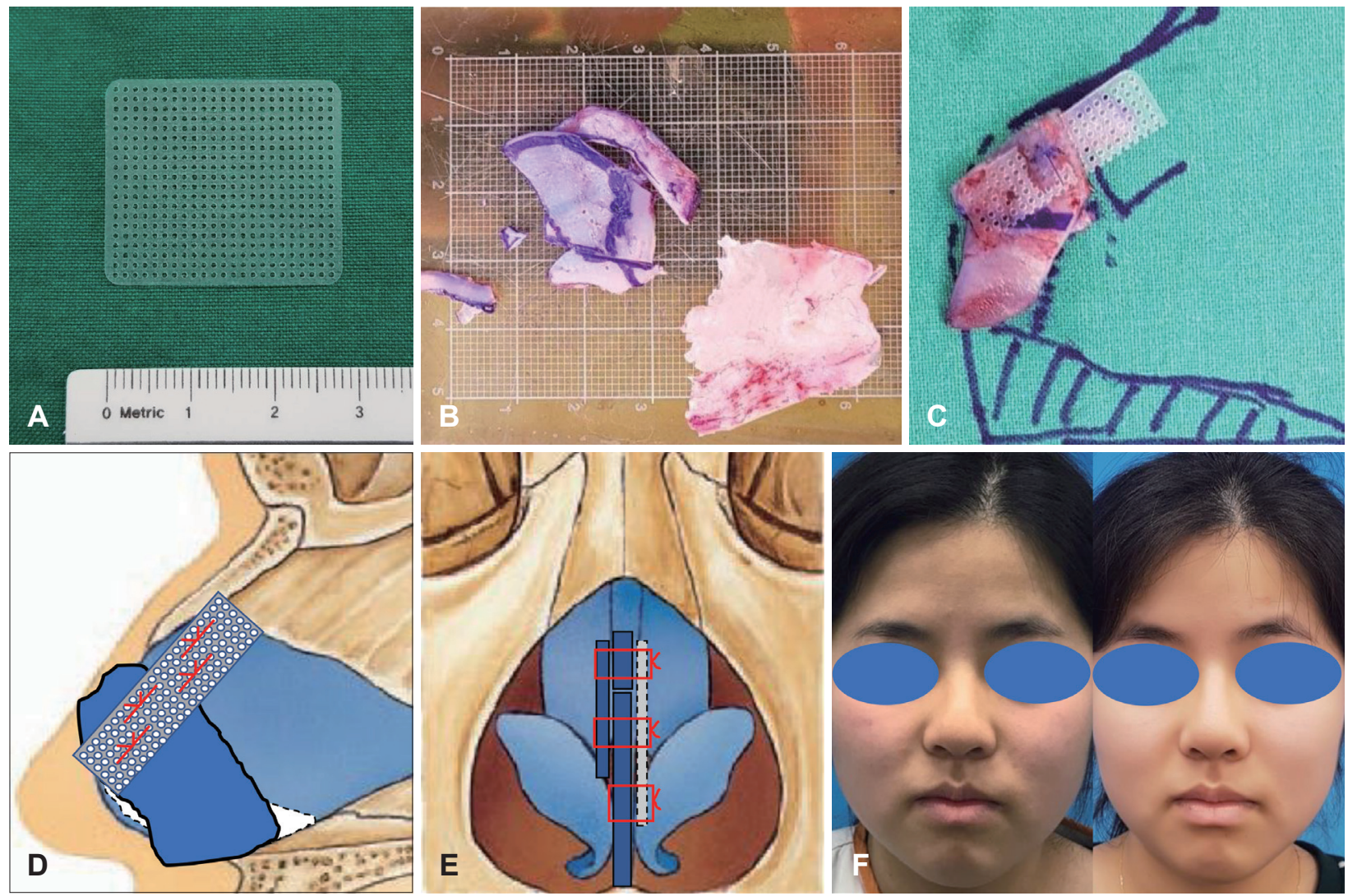

Fig. 1. Extracorporeal septoplasty using PLGA plate. A: The shape and size of PLGA plate was shown. B: The harvested septal cartilage was insufficient to use as a graft material in extracorporeal septoplasty. C: L-strut was reconstructed using septal cartilage and a PLGA plate. D and E: Schematic drawings of septal reconstruction using septal cartilage and a PLGA plate. F: Patient's photo taken preoperatively and postoperatively at 5 months. PLGA, polylactic-co-glycolic acid.
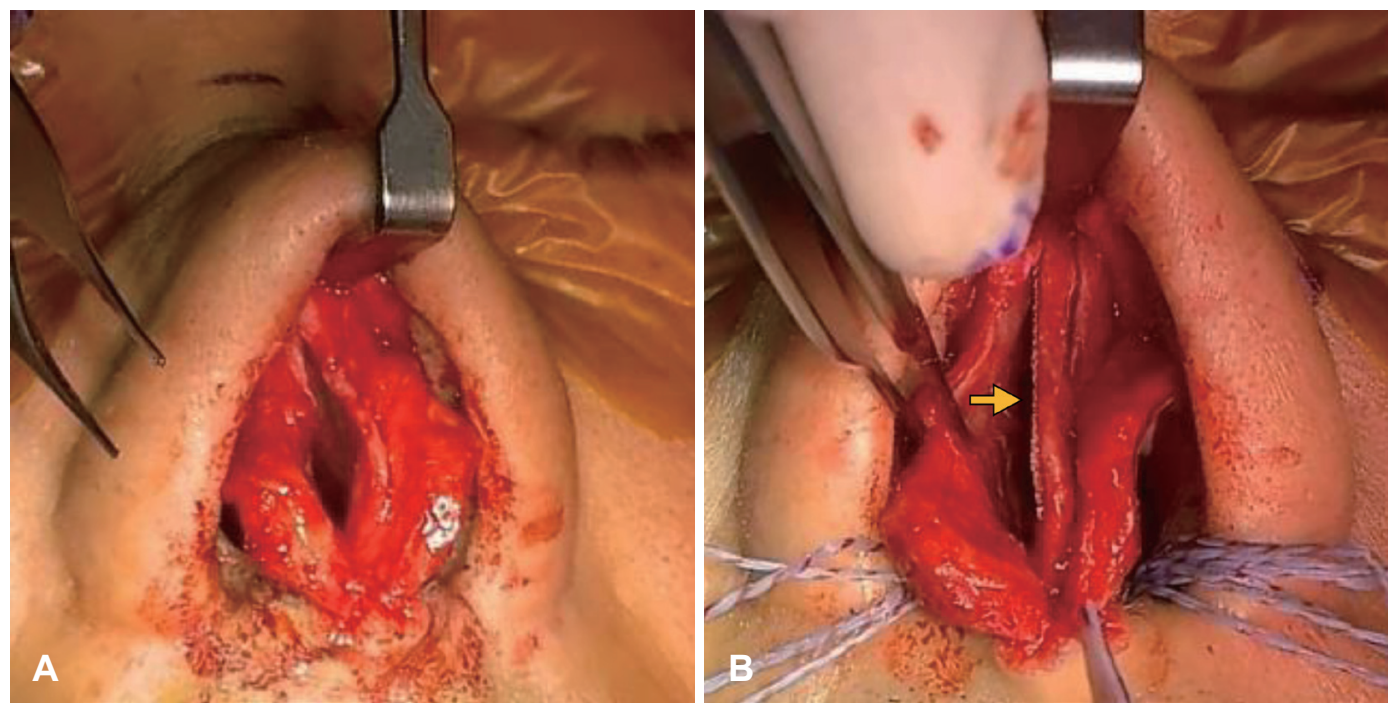

Fig. 2. Correction of dorsal septal deformity using PLGA plate. A: Intraoperative photo shows dorsal deformity of nasal septum. B: A unilateral spreader graft was applied using a PLGA plate, and septal deviation is corrected. The arrow points to the PLGA plate. PLGA, polylactic-co-glycolic acid. 

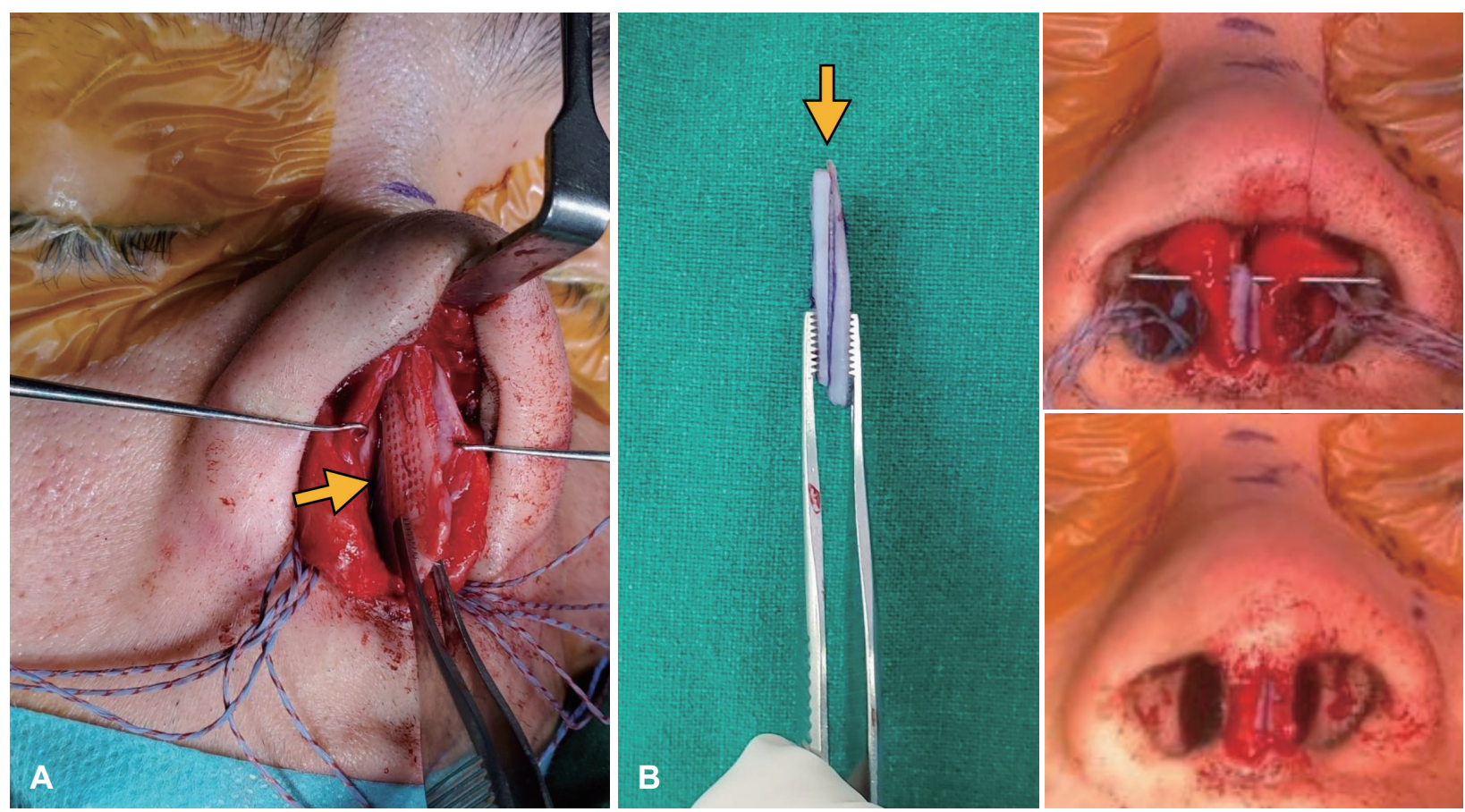

Fig. 3. Pictures during surgery using PLGA plate. A: PLGA plate was used as a batten graft on one side of the L-strut. B: The septal cartilage wrapped around the PLGA plate on both sides to create a columellar strut graft. And the graft was transplanted into the columellar. The arrows point to the PLGA plate. PLGA, polylactic-co-glycolic acid.

\section{결 과}

총 33명의 환자가 연구에 포함되었고, 남성이 28명(84.8\%), 여성은 5명(15.2\%)이었다. 연령 분포는 18-76세였으며, 평균 연령(median age)은 32세였다. 비중격 외비성형술을 받은 환 자는 21명(63.6\%), 비중격 체외교정술을 받은 환자는 12명 (36.4\%)이었으며 비내접근술을 이용한 환자는 없었다. 각각 의 환자에 대한 진단은 비중격 만곡증이 20 명, 비중격 만곡 증과 사비로 진단받은 환자가 13 명이었고, 비중격 외비성형 술을 받은 환자 중 한 명의 환자는 8개월 전 수술 이후 재수 술을 한 환자였다. 수술 이후 외래 경과 관찰 기간은 6-32개 월, 평균 추적 관찰 기간은 18.03 개월이었다(Table 1).

수술 중 다양한 이식편(graft)을 시행하기 위한 비중격연골 의 양이 부족한 경우 PLGA plate를 비중격연골 대신 사용하 였다. PLGA plate 이식방법은 비중격 체외교정술 시 L형 지 주를 고정하기 위해 사용한 경우가 12 명, 일측 펼침이식 17 명, 양측 펼침이식 10 명, 버팀목이식이 3 명, 비중격 연장이식을 위한 지지 2명, 비주지주이식의 지지 3명이었다(Table 2).

수술 후 모든 환자에 대해 주기적으로 비내시경을 포함한 신체검사를 하였으며, 추적 관찰 기간 중 PLGA plate 이식물 의 돌출 및 노출이 발생한 환자는 없었다. 추적 관찰 기간 중 일측 펼침이식을 시행한 환자 중 1 명에서 술후 2 주째에 비주 에 발적이 발생하였고, 양측 펼침이식을 시행한 환자 중 1 명
Table 1. Demographic data of the 33 patients

\begin{tabular}{lc}
\hline Sex & \\
Male & $28(84.8)$ \\
Female & $5(15.2)$ \\
Age (year) & $37.27 \pm 15.79$ \\
Surgery & \\
$\quad$ Septorhinoplasty & $21(63.6)$ \\
$\quad$ Extracorporeal septoplasty & $12(36.4)$ \\
Diagnosis & \\
$\quad$ Deviated nasal septum & $20(60.6)$ \\
$\quad$ Deviated nasal septum, deviated nose & $13(39.4)$ \\
Mean follow up duration (month) & $18.03 \pm 9.39$
\end{tabular}

Values are presented as $\mathrm{n}(\%)$ or mean \pm standard deviation

Table 2. Applications of polylactic-co-glycolic acid plate in the 33 patients

\begin{tabular}{lc}
\hline \multicolumn{1}{c}{ Application } & No. of patients \\
\hline Graft & \\
Reinforcement of L-strut & 17 \\
Unilateral spreader graft & 10 \\
Bilateral spreader graft & 2 \\
Supporting of septal extension graft & 3 \\
Reinforcement of columellar strut graft & 12 \\
Fixing a extracorporeal septoplasty & 3 \\
Batten graft & \\
\hline
\end{tabular}

$\overline{\text { In some patients, more than one application has been applied }}$ 
Table 3. Complications of polylactic-co-glycolic acid plate in the 33 patients

\begin{tabular}{lc}
\hline \multicolumn{1}{c}{ Complications } & No. of patients (\%) \\
\hline Erythematous change of columella & $1(3.03)$ \\
Granulation formation & $1(3.03)$ \\
Pain on nasal dorsum & $1(3.03)$ \\
\hline
\end{tabular}

에서 술후 4주째에 좌측 비익 경계절개선 부위에 육아종이 발생하였으나 항생제와 보존적 치료로 호전되어 경과 관찰하 였다. 양측 펼침이식과 버팀목이식을 같이 시행했던 1명의 환 자가 술후 4주째에 비배부 통증을 호소하였는데, 진통제를 1 주일간 복용 후 통증이 조절되었다(Table 3).

\section{고 찰}

비중격 외비성형술 또는 비중격 체외교정술에서 변형된 L형 지주를 효과적으로 교정하고, 비배부를 반듯하게 하며, 내비 밸브의 기능적 개선을 목적으로 채취한 비중격연골을 이용 하여 펼침이식이나 상외측비연골을 이용한 자가펼침이식( $\left(\mathrm{au}^{-}\right.$ tospreader graft)을 시행하게 된다. ${ }^{14)}$ 그러나, 이전에 받은 외 상으로 인한 비중격연골의 골화나 변형으로 자가 비중격연골 을 충분히 얻지 못하는 경우 비중격 이외의 연골을 채취하여 야 한다. 하지만 자가연골이식으로 많이 사용하는 이개연골 이나 늑연골은 채취하는데 추가로 시간이 더 소요되고 공여 부의 합병증 발생의 가능성이 있는 단점이 존재한다. 이러한 이유로 최근 이물이식의 필요성이 점차 증가하고 있다. ${ }^{15}$

이물이식의 재료 중 expanded polytetrafluoroethylene, pHDPE, silicone 등의 재료는 주변 조직으로 흡수되지 않고 분해되지 않아 migration, extrusion, 이물반응으로 인한 감염 등의 위험성이 있다. ${ }^{16)}$ 따라서, 비흡수성을 대신하여 흡수성 이물이식 재료가 소개되어 왔는데, polycaprolactone (PCL) 은 낮은 온도에서도 잘 녹는 특성과 생체 적합성을 인정받아 $3 \mathrm{D}$ printing 기술을 이용한 두개안면부 재건이나 약물전달 체 재료로써 각광을 받고 있다. ${ }^{17)}$

그러나 PCL plate (Osteomesh ${ }^{\mathrm{TM}}$; $39 \times 25 \times 1.25 \mathrm{~mm}$; Osteopore, Singapore)는 $1.25 \mathrm{~mm}$ 로 본 연구에 사용된 $0.3 \mathrm{~mm}$ 의 PLGA plate에 비해 두께가 두꺼워 체내 가수 분해 속도 가 24개월 이상 필요하며 체내에서 이산화탄소와 물로 가수 분해되지만 주변 $\mathrm{pH}$ 에 영향을 줄 수 있다. ${ }^{18)}$ 따라서 분해 속 도에 따른 돌출, 감염 등의 합병증 발생이 높을 수 있고, Kim 과 $\mathrm{Choi}^{17)}$ 에 의하면 수술 직후 환자가 강직성(stiffness)을 호 소할 수 있다는 단점이 있다. 또한 PCL plate의 급여 수가가 379730원인 반면 PLGA plate는 비급여 수가 196000원으로 비용적인 측면에서도 효율적이다.
Crystalline polymer인 PDS의 경우 구멍(perforation)이 있는 $0.15 \mathrm{~mm}$ plate와 구멍이 없는 $0.25 \mathrm{~mm}$ plate로 구분되 는데, 얇은 plate는 frame를 지지할 수 있는 강도가 부족하기 때문에 두꺼운 $0.25 \mathrm{~mm}$ plate를 주로 사용하게 된다. ${ }^{19)} \mathrm{PDS}$ 는 체내에서 8 개월 이내에 분해되어 흡수되지만, $0.25 \mathrm{~mm}$ plate는 사용시 바늘을 이용하여 구멍을 만들어야 하는 불편 함이 있고 점막연골막피판(mucoperichondrial flap)으로의 적절하지 못한 혈류 공급으로 인해 saddle nose와 같은 합병 증 발생 빈도가 더 높아질 수 있다는 보고가 있다. 8,20$)$

PLGA는 폴리에스터 계열로 PGA와 PLA의 합성 고분자 이며, 친수성인 glycolic acid와 소수성인 lactic acid 사이의 에스터결합 붕괴로 결국 물과 이산화탄소로 가수분해된다. ${ }^{21}$ PLGA는 PGA와 PLA의 혼합 비율에 따라 분해 속도가 조 절되지만 일반적으로 6 개월 이내에 분해되는 것으로 알려져 있다. ${ }^{22)}$ 본 연구에서 환자들의 수술 후 외래 추적 관찰 기간 은 6-32개월이었으며, 이는 PLGA plate가 생체 내에서 분해 되기에 충분한 시간으로 생각할 수 있고, 추적 관찰 기간 동 안 감염이나 염증과 같은 주요 합병증은 발생하지 않았다. 3 명 의 환자가 비주의 발적, 절개선의 육아조직 생성과 비배부 통 증이 각각 발생하였는데, 모두 수술 후 4주 이내에 발생하였 으므로 PLGA plate의 분해과정에서 생기는 염증 반응과의 관련성은 없다고 볼 수 있으며 모두 보전적인 치료로 호전되 었다. 생체에 무해한 물과 이산화탄소로 분해가 되기 때문에 PLGA plate는 생체 안정성이 보장되고, 이물반응 발생 가능 성이 상대적으로 낮은 것으로 알려져 있다. ${ }^{15,23)}$ 또한, 본 연구 에 사용된 PLGA plate는 구멍이 있기 때문에 수술 중 술자 가 구멍을 만들지 않아도 되는 이점이 있고 얇은 두께에 비해 재질이 단단하여 적절한 기계적 강도를 제공할 수 있어서, 일 측 펼침이식, 양측 펼침이식, 비중격 연장이식, 비주지주이식, 버팀목이식 등 서로 다른 위치에서도 이식물의 돌출 위험을 줄이면서 유용하게 응용될 수 있다는 가능성을 확인할 수 있었다.

PLGA는 체내에서 분해되며 PCL과 비슷하게 연골 형성을 일으키며 ${ }^{24)}$ 분해 과정 중 주변 조직의 $\mathrm{pH}$ 를 국소적으로 감소 시키면서 염증 반응을 일으키며 흡수되고, 따라서 주변 조직 의 상처 치유에 영향을 줄 수 있다. ${ }^{25)}$ 본 연구의 환자들은 감 염 또는 염증반응에 의한 구축 등 심각한 부작용은 발생하지 않았지만 눈에 띄지 않는 염증반응으로 인해 외형적 변화가 서서히 진행될 가능성은 있다. 따라서, 향후 1 년 이상의 장기 간의 추적 관찰을 통하여 코 높이의 변화나 코 모양의 변형과 같은 상처치유 과정에서 보일 수 있는 변화를 장기간에 걸쳐 관찰할 필요가 있다. 또한, 조직치유 과정에 영향을 미칠 수 있으므로 비첨 부위나 비주 부위처럼 혈류의 공급에 민감하 
고 피부가 얇은 부위에 PLGA plate를 사용할 때는 각별한 주의를 기울여야한다.

결론적으로 PLGA plate는 비중격연골의 심한 변형이나 골 화로 채취한 비중격연골의 양이 충분하지 않을 경우 비중격 이나 비주 등 제한적인 위치에 신중하게 사용한다면, 비중격 외비성형술 및 비중격 체외교정술 시 안전하고 유용한 이식 재료로 사용될 수 있을 것이라 생각한다.

\section{Acknowledgments}

I would like to thank colleagues of our institute for support of time to finish the research. I would also like to thank the patients who provided photos for this study for the advancement of septorhinoplasty.

\section{Author Contribution}

Conceptualization: Yong Min Kim, Soo Kyoung Park, Ki-Sang Rha. Data curation: Min-Su Kim, Se Yeon Im. Formal analysis: KiSang Rha. Resources: Soo Kyoung Park. Supervision: Ki-Sang Rha. Writing — original draft: Jae-Yoon Kang. Writing_review \& editing: Jae-Yoon Kang, Yong Min Kim.

\section{ORCIDs}

Yong Min Kim

Jae-Yoon Kang

Soo Kyoung Park

Ki-Sang Rha https://orcid.org/0000-0001-5414-8332

https://orcid.org/0000-0003-0599-9493

https://orcid.org/0000-0002-5163-536X

https://orcid.org/0000-0001-9981-057X

\section{REFERENCES}

1) Maguire AJ. Open rhinoplasty approach to the deviated nose. Facial Plast Surg 1989;6(2):83-7.

2) Sazgar AA, Teimouri Y, Arjang S, Amali A, Most SP. Severe deviated nose treatment: Importance of preserving the dorsal septal remnant. Eur Arch Otorhinolaryngol 2019;276(5):1349-54.

3) Depeyre A, Schlund M, Delmotte C, Dupuch V, Pham Dang N, Barthélémy I. Extracorporeal septorhinoplasty: Technical note. J Stomatol Oral Maxillofac Surg 2020;121(5):579-84.

4) Oliveira PW, Pezato R, Gregório LC. Deviated nose correction by using the spreader graft in the convex side. Braz J Otorhinolaryngol 2006;72(6):760-3.

5) Pham AM, Tollefson TT. Correction of caudal septal deviation: Use of a caudal septal extension graft. Ear Nose Throat J 2007; 86(3):142, 144.

6) Davis RE, Foulad AI. Treating the deviated or wide nasal dorsum. Facial Plast Surg 2017;33(2):139-56.

7) Rimmer J, Ferguson LM, Saleh HA. Versatile applications of the polydioxanone plate in rhinoplasty and septal surgery. Arch Facial Plast Surg 2012;14(5):323-30.

8) Tweedie DJ, Lo S, Rowe-Jones JM. Reconstruction of the nasal septum using perforated and unperforated polydioxanone foil. Arch Facial Plast Surg 2010;12(2):106-13.

9) Won HR, Kim YS, Won JE, Shin YS, Kim CH. The application of fibrin/hyaluronic acid-poly (1-lactic-co-glycolic acid) construct in augmentation rhinoplasty. Tissue Eng Regen Med 2017;15(2): 223-30.

10) Oh GJ, Choi J, Kim TK, Jeong JY, Kim JH, Kim S, et al. Feasibility of a polydioxanone plate as an adjuvant material in rhinoplasty in Asians. Arch Plast Surg 2019;46(2):152-9.

11) Rimmer J, Saleh H. Use of polydioxanone plate in septal reconstruction. Facial Plast Surg 2013;29(6):464-72.

12) Kim YH, Kim BJ, Jang TY. Use of porous high-density polyethylene (Medpor) for spreader or extended septal graft in rhinoplasty: Aesthetics, functional outcomes, and long-term complications. Ann Plast Surg 2011;67(5):464-8.

13) Jeong JH, Kim BH, Kim DH, Kim BK, Pak CS, Kim EH, et al. Cartilage suspension using a poly (lactic-co-glycolic) acid system. J Plast Reconstr Aesthet Surg 2017;70(7):937-45.

14) Stal S, Hollier L. The use of resorbable spacers for nasal spreader grafts. Plast Reconstr Surg 2000;106(4):922-8; discussion 929-31.

15) Demirkan F, Arslan E, Unal S, Aksoy A. Irradiated homologous costal cartilage: Versatile grafting material for rhinoplasty. Aesthetic Plast Surg 2003;27(3):213-20.

16) Mella J, Christophel J, Park S. Are alloplastic implants safe in rhinoplasty? Laryngoscope 2020;130(8):1854-6.

17) Kim SH, Choi JY. Surgical outcomes and complications of septal extension graft supported by $3 \mathrm{D}$ printed polycaprolactone plate. Laryngoscope 2020;130(7):1680-5.

18) Park YJ, Cha JH, Bang SI, Kim SY. Clinical application of threedimensionally printed biomaterial polycaprolactone (PCL) in augmentation rhinoplasty. Aesthetic Plast Surg 2019;43(2):437-46.

19) Fuller JC, Levesque PA, Lindsay RW. Polydioxanone plates are safe and effective for L-strut support in functional septorhinoplasty. Laryngoscope 2017;127(12):2725-30.

20) Boenisch M, Mink A. Clinical and histological results of septoplasty with a resorbable implant. Arch Otolaryngol Head Neck Surg 2000; 126(11):1373-7.

21) Reed AM, Gilding DK. Biodegradable polymers for use in surgerypoly (glycolic)/poly (Iactic acid) homo and copolymers: 2 . In vitro degradation. Polymers 1981;22(4):494-8.

22) Park $\mathrm{CH}$, Kim DK. The trend of biomaterials in facial plastic and reconstructive surgery. Korean J Otorhinolaryngol-Head Neck Surg 2014;57(10):651-6.

23) Makadia HK, Siegel SJ. Poly lactic-co-glycolic acid (PLGA) as biodegradable controlled drug delivery carrier. Polymers (Basel) 2011;3(3):1377-97.

24) Mendelson A, Ahn JM, Paluch K, Embree MC, Mao JJ. Engineered nasal cartilage by cell homing: A model for augmentative and reconstructive rhinoplasty. Plast Reconstr Surg 2014;133(6):134453.

25) Yoon SJ, Kim SH, Ha HJ, Ko YK, So JW, Kim MS, et al. Reduction of inflammatory reaction of poly (d,1-lactic-co-glycolic Acid) using demineralized bone particles. Tissue Eng Part A 2008;14(4):53947. 